\title{
Specifics of contrastive teaching Russian as a foreign language (based on the example of Swahili)
}

\section{Características de la enseñanza contrastiva del idioma ruso a los extranjeros (ejemplo del Idioma suajili)}

\author{
Zharkova Elena \\ MGIMO MID RF, Moscow, Russian Federation \\ ORCID: https://orcid.org/0000-0002-9460-3325 \\ Nazartseva Ekaterina $(\mathbb{D} *$ \\ Peoples' Friendship University of Russia (RUDN University), Moscow, Russian Federation \\ ORCID: https://orcid.org/0000-0001-5466-4863

\section{Cherkashina Elena} \\ Moscow State University of Civil Engineering (National Research University), Moscow, \\ Russian Federation \\ ORCID: http://orcid.org/0000-0002-1613-0147
}

Received 09-08-20 Revised 10-10-20

*Correspondence

Email: Nazartseva@gmail.com
Accepted 20-12-21 On line 02-05-21

Cite as:

Zharkova, E., Nazartseva, E. \& Cherkashina, E. (2021). Specifics of contrastive teaching Russian as a foreign language (based on the example of Swahili, 9(SPE2), e970. Doi: http://dx.doi.org/10.20511/pyr2021.v9nSPE2.970 


\section{Summary}

The the article proves the crucial role of principles of comparative/contrastive teaching Russian. The author proves that Russian methodologists understand the need to take into consideration students' mother tongue when teaching Russian as a foreign language. The article contains general characteristics of Swahili and comparative analysis of Russian and Swahili lexical and grammatical systems as the basis for the system of teaching Russian as a foreign language.

Keywords: contrastive teaching, consideration to the mother tongue, Russian as a foreign language.

\section{Resumen}

El artículo demuestra que el principio principal de la enseñanza del idioma ruso son los principios del aprendizaje comparativo / contrastivo. Se demuestra que la escuela metodológica rusa proviene de la necesidad de tener en cuenta el idioma nativo al enseñar un idioma extranjero. Se proporciona una característica general del idioma suajili. Se realiza un análisis comparativo del sistema léxico-gramatical del idioma ruso y el idioma suajili como base para construir un sistema de enseñanza de la lengua rusa como idioma extranjero.

Palabras clave: aprendizaje contrastivo, consideración de la lengua materna, ruso como lengua extranjera.

\section{Introducción}

Teaching Russian as a foreign language to representatives of different nationalities has its own specifics. The majority of Russian methodologists share the opinion that the crucial principles of teaching Russian as a foreign language are consideration to the mother tongue, comparative/contrastive teaching Russian as a foreign language, and language-oriented teaching.

Nonetheless, researchers had different opinion on them in different times, which changed from full recognition to absolute rejection. The majority of Russian scholars (I.L. Bim, R.K. Minyar-Beloruchev, E.I. Passov, I.N. Vereshchagina and others) have a positive view of these principles. Many foreign methodologists, however, see them non-effective.

A.A. Leontyev, I.A. Zimnyaya, V.G. Gak, V.N. Yartseva, V.N. Vagner, C. James, G. Nickel, G. Helbig, S. Gass, S. Selinker, T. Odlin, V. Nemzer suppose that one should take into consideration the system of students' mother tongue when teaching Russian as a foreign language. Learning Russian as a foreign language presupposes comprehension of a new code and the rules of code switching. They also point out that a person switches from the mother tongue to Russian through mediated knowledge of the foreign language. At this stage the system of of rules in the mother tongue plays a mediating role. A person codes grammar and semantics in the categories and linguistic means of the mother tongue and then tries to give a deliberate translation of a statement into a foreign language. Therefore, when comprehending a foreign language there are two speech reproduction and language coding systems functioning in students' mind.

At the initial stage students haven't got enough experience in the use of their foreign language as they haven't fully comprehended the recoding rules yet. They make up for this insufficient experience by using their mother tongue skills in practicing foreign language, consciously or (most often) unconsciously. Such practice usually halts the formation of foreignlanguage skills. Of course, as S.L. Rubinstein pointed out, "there is nothing fatal in the halting nature of interference" (Rubinstein, 1946, p. 560). We understand students' unconscious reliance 
on their mother tongue skills in foreign-language communication as a consistent psychological phenomenon of transference. In this context, the effectiveness of the method should depend on the following factors: the degree of manageability of an unconscious transference and possibilities for a conscious transference. Thus, the problem is to provide a positive transference. Psychologists admit that a positive transference is based on conscious actions and may be possible in case of similar components. Hence, the similarity of material, which is the object of actions, is considered as one of the most important conditions determining the transference. Identifying the possibilities of transference in skills inevitably results in the static study of transference, i.e. language transference. A.A. Leontyev and I.A. Zimnyaya believe that comparative analysis of the psychological nature of communicative act should be conducted in different languages for training purposes and, therefore, provide a dynamic classification of different ways to produce speech (Zimnyaya, 1976).

The problem of transference is related to the complexity of interrelations between the language skills themselves. The main difficulties already arise when skills are rebuilt (if a way to do the task need changing), but it is especially difficult to achieve high results when a new method to complete the tasks is applied. There is an opinion that one should find more specific dialectic educational models focused on correcting certain junctions of speech reproduction mechanism rather than replacing them with new ones. A.A. Leontyev and I.A. Zimnyaya suppose that the mechanism of a foreign-language speech may be provided by the following skills: 1) "the speaking skills in the mother tongue which should be transferred to a new language material and mainstreamed", 2) "the skills that were built in the mother tongue and should get corrected in a foreign language", 3) "the skills that need rebuilding" (Zimnyaya, 1976, p.38). According to the researchers, the modern methodology pays insufficient attention to the skills from the first group and overestimates the importance of forming new skills.

\section{Problem statement}

In this study we would like to consider certain aspects of interrelations between the structures of Russian (the target language) and Swahili (the source language) in order to transfer certain language skills which is important for the professors to take into account when teaching African students.

The choice of Swahili (as a language used for an interlinguistic comparative analysis) is linked to the fact that although English used to be a traditional language of teaching Russian to the African students from former British colonies, nowadays such language-focused methods are not quite correct as the language situation in Africa has changed dramatically. For instance, the recent decades noted Swahili, the biggest of Bantu language group in all Africa, actively developing as a lingua franca in East and Central Africa: a number of accounts say (Interracial and interethnic relationships in modern Tanzania, 2008) that it is spoken by 100 million people (as the mother tongue, as wells as the first or the second language). Swahili is one of the most wide-spread African languages, it is spoken in Kenya, Tanzania, Uganda, Mozambique, Somali, Ruanda, Burundi, Zambia, and Malawi; it is one of the UN and OAU working languages. Such a development is related to the fact that Swahili has never been associated with any tribe, so its use as a lingua franca has never caused any negative reaction from numerous African tribal groups. Moreover, the language has been announced as the state language in Tanzania and Kenya, dominating in all communication spheres, in text and fiction books.

Methodology: descriptive, comparative, comparative and analytical, contrastive methods, etc.

\section{Discussion}

\section{General Characteristics of Swahili}


Africanists' recent researches show that Swahili is spoken by $90 \%$ of Tanzanian population; the vast majority of Tanzanians use Swahili as their mother tongue or the only language they think in. English classes start only at secondary schools, and 94\% of Tanzanian schoolchildren and students admit that they hardly read and understand English text and fiction books (Interracial and interethnic relationships in modern Tanzania, 2008). It should be noted that nowadays the Tanzanian government is working actively to train national specialists, every year more than 200 Tanzanian students come to study at Russian universities. In this connection, we prefer using Swahili instead of English in the comparative analysis when teaching Russian as a foreign language to this group of students. The Swahili language is rather new for the professors who teach Russian as a foreign language, there are almost no studies devoted to the comparative analysis of Russian and Swahili language structures in the context of teaching Russian as a foreign language.

The phonetic system of Swahili is characterized with rhythmic alternations of vowels and consonants. The language has 33 phonemes: 5 vowels and 28 consonants. The principles of syllabification in Russian and Swahili are different. While there are syllables in Russian, represented with a single vowel, Swahili syllables can contain only a single consonant: nchi "country" (n-chi). Additionally, Swahili speakers have difficulties when pronouncing consonant codas in the middle or at the end of the word since there is no additional vowel appearing after the consonant in Swahili, whereas it is a common phenomenon in the Russian language: in this position there is semi-vowel "y" (Rus. "b") after hard consonants and "i" after palatalized consonants. Speaking of accent, it is quantitative both in Russian and in Swahili, but the latter always has it fixed (the penultimate). In addition, the nasal $\mathrm{n}$ and $\mathrm{m}$ in the onset are pronounced without vowel sounds and somehow stressed. As for morphological structure, Swahili is an agglutinative language with some inflexional traits. The students have a number of difficulties caused by the morphological structure of Russian words, identification and definition of the morphemes. A Swahili word may contain prefixes, root, infixes, and suffixes. Additionally, a content word cannot be represented with a single root as there are no root content words in Swahili. The smallest lexical unit consists of a root and a prefix (as a derivational morpheme). The root carries aspects of general semantic content, while the prefix is a bound affix and a part of each word, which starts words and determines the agreement to the other parts of speech. The infix, if any, precedes the root and has a grammatical meaning (objective and relative concord, negative particles, and reflexive particles). The Swahili suffixes follow the root and can be either bound (locative suffix e, determining the agreement, like prefixes) or free (the suffixes changing the word's meaning). The main grammatical specific of Swahili is a complex system of nominative classes related to derivation and agreement. The nominative classification is a logical classification of people, objects and phenomena: all nouns are divided into classes depending on their denotative relation and the following factors:

Class 1 - nouns which denote people;

Class 2 - first-class nouns in plural;

Class 3 - nouns which denote plants and trees;

Class 4 - third-class nouns in plural, etc.

\section{Contrastive analysis of Russian and Swahili}

Contrastive analysis of two linguistic systems (along with some other methods like analyzing mistakes) will help to understand the nature of the transferences and devise strategies of teaching a specific language which would provide the language bearers' conscious transference, preventing and dealing with their interference. Contrastive analysis presupposes:

a) grammar structures from both languages, described according to the comparable theoretical basis; 
b) identification of the language areas to compare (e.g. word order, semantics of cases, etc.);

c) process of comparison;

d) formulation of conclusions, important for teaching methodology. Comparing two languages presupposes the following possible relations of Russian or the first language (L1) and the target language and the second language (L2): 1) one L1 element is consistent with one or two L2 elements; 2) one L2 element has no correspondence with L1; 3) one L1 element has no correspondence with L2; 4) two or more L2 elements are consistent with one L1 element; 5) one $\mathrm{L} 1$ element is identical to one L2 element. The fifth case may result in a positive transference. Cases $1-4$ may lead to a negative transference, i.e. to a mistake. 1970s saw numerous researches, aimed to estimate the proportion of mistakes related to a negative transference. The results varied from 20 to 50\% (Lions, p. 325), which leads to conclusions about its importance and the need to take it into consideration.

Students usually have difficulties with agreement between the noun and the adjective/the pronoun. In this article we would like to demonstrate the way to create favorable conditions for a positive transference through comparing grammatical gender category in Russian and class category in Swahili. Russian nouns are divided into masculine, feminine and neuter genders, with semantic gender agreement (the names of male individuals are masculine, the names of female individuals are feminine) or formal gender agreement (inflexion).

The gender category plays a minor role in English: all animate nouns are divided into masculine and feminine, agreeing to the pronouns "he" and "she"; all inanimate nouns are of neuter gender, agreeing to the pronoun of it.

The null gender agreement in English (my new book - моя новая книга, my new house - мой новый дом, my new coat - мое новое пальто, my new friends - мои новые друзья) and the differences in substituting nouns with personal pronouns lead to typical mistakes in agreement between Russian words:

1) This is mother. She is here. Это мама. Она тут. This is a book. It is here. Это книга. Оно тут;

2) мой книга - my book, мой окно - my window, мой друзья - my friends. Unlike Russian, there is no gender category and even gender classification in Swahili (like in any Bantu language).

However, "the term of gender derives from a very general "class" or "species" (Genus), which was used to denote pronouns' correspondence (I) and agreement (II) with adjectives. French...and Spanish nouns are divided into two genders, Swahili nouns are divided, at least, into six genders..." (Lions, p. 461).

Swahili nouns are classified not according their genders, but according to their nominative classes (different studies identify from 8 to 21 classes depending on the criteria of identification); all the nouns are related to one or another class depending on their denotative correspondence to the notion, size and shape of the referents, etc., e.g.: I nominative class, or so-called human class (nouns denoting people (considering their nationality, profession, family relationships, age, etc.) and the following nouns: mdudu - an insect, mnyama - an animal); II nominative class or tree class (nouns denoting trees and plants, some natural phenomena and parts of the body); III nominative class or "round item class" (nouns denoting round items: the sun - jua, an eye - jicho; 
besides, there are nouns with different semantics (jiko - a kitchen, jina - a name); their class is not semantically motivated. Consider several examples of agreement for some of the nominative classes (Gromova, 1995).

\begin{tabular}{|c|c|c|c|c|c|c|c|c|c|}
\hline \multirow{2}{*}{\multicolumn{2}{|c|}{ Class }} & \multicolumn{2}{|c|}{1} & \multicolumn{2}{|c|}{2} & \multicolumn{2}{|c|}{3} & \multicolumn{2}{|c|}{4} \\
\hline & & Sing. & Pl. & Sing. & Pl. & Sing. & Pl. & Sing. & Pl. \\
\hline \multicolumn{2}{|c|}{ Prefix forms } & $\begin{array}{l}\mathrm{m}- \\
\mathrm{mw}-\end{array}$ & $\begin{array}{c}\text { wa- } \\
\text { w- }\end{array}$ & $\begin{array}{l}\mathrm{m}- \\
\mathrm{mw}-\end{array}$ & mi- &,$- \mathrm{ji}-, \mathrm{j}$ & ma- & ki-, ch- & vi-, vy- \\
\hline \multicolumn{2}{|c|}{ Adjective prefixes } & $\begin{array}{l}\mathrm{m}- \\
\mathrm{mw}-\end{array}$ & $\begin{array}{l}\text { wa-, } \\
\text { w- }\end{array}$ & $\begin{array}{l}\mathrm{m}- \\
\mathrm{mw}-\end{array}$ & $\begin{array}{l}\text { mi-, } \\
\text { my- }\end{array}$ &,$- \mathrm{j}-$ & ma- & ki-, ch- & vi-, vy- \\
\hline \multicolumn{2}{|c|}{ Possessive particle } & \multicolumn{2}{|c|}{ wa } & wa & ya & la & ya & cha & vya \\
\hline \multirow{6}{*}{$\begin{array}{l}\text { Possessive } \\
\text { adjectives }\end{array}$} & My & \multicolumn{2}{|c|}{ wangu } & wangu & yangu & langu & yangu & changu & vyangu \\
\hline & Your & \multicolumn{2}{|c|}{ wako } & wako & yako & lako & yako & chako & vyako \\
\hline & His & \multicolumn{2}{|c|}{ wake } & wake & yake & lake & yake & chake & vyake \\
\hline & Our & \multicolumn{2}{|c|}{ wetu } & wetu & yetu & letu & yetu & chetu & vyetu \\
\hline & Your & \multicolumn{2}{|c|}{ wenu } & wenu & yenu & lenu & yenu & chenu & vyenu \\
\hline & Their & \multicolumn{2}{|c|}{ wao } & wao & yao & lao & yao & chao & vyao \\
\hline \multirow{2}{*}{$\begin{array}{c}\text { Demonstrative } \\
\text { pronouns }\end{array}$} & This & huyu & hawa & huu & hii & hili & haya & hiki & hivi \\
\hline & That & ule & wale & ule & ile & lile & yale & kile & vile \\
\hline $\begin{array}{l}\text { Interrogative } \\
\text { pronoun }\end{array}$ & What & yupl & wapi & upi & ipi & lipi & yapl & kipi & vipi \\
\hline $\begin{array}{l}\text { Relative } \\
\text { particle }\end{array}$ & which|who & -ye- & $-0-$ & $-\mathrm{O}-$ & -ye- & -lo- & -yo- & -cho- & -vyo- \\
\hline \multirow{3}{*}{$\begin{array}{c}\text { Other } \\
\text { pronouns }\end{array}$} & All & - & wote & Wote & yote & lote & yote & chote & Vyote \\
\hline & Any & $\begin{array}{c}\mathrm{Ye} \\
\text { yote }\end{array}$ & $\begin{array}{l}\text { Wo } \\
\text { wote }\end{array}$ & $\begin{array}{c}\text { Wo } \\
\text { wote }\end{array}$ & $\begin{array}{c}\text { Yo } \\
\text { yote }\end{array}$ & $\begin{array}{l}\text { Lo } \\
\text { lote }\end{array}$ & $\begin{array}{c}\text { Yo } \\
\text { yote }\end{array}$ & $\begin{array}{l}\text { Cho } \\
\text { chote }\end{array}$ & $\begin{array}{l}\text { Vyo } \\
\text { vyote }\end{array}$ \\
\hline & many & - & wengi & mwingi & mingi & jingi & mengi & kingi & vingi \\
\hline
\end{tabular}

Each noun has its own specific prefix, the indicator of a class, which is repeated in every word related to a class. Along with that, each class has its own singular and plural form prefix. The indicator of the agreement class goes to the agreed word, indicating their grammatical and syntactical interrelations: mtu mzuri - the man is handsome, watu wazuri - the men are handsome; кitabu changu - my book, vitabu vyangu - my books; msichana ambaye - the girl, who, wasichana ambao - the girls, who... As the gender category in Russian, the Swahili class category helps to choose the right form (singular or plural), as well as to agree nouns with adjectives, pronouns, etc. Both in Russian and in Swahili almost all modifiers of nouns which are grammatically related to them agree to nouns in accordance with a gender and a singular/plural form.

\section{Conclusiones}

To summarize, the theory of language comprehension has been observed in a more balanced way, so, being the key factors of the educational process, the impact of the mother tongue and contrastive analysis are the main focus of teaching Russian as a foreign language now.

Nowadays contrastive teaching Russian as a foreign language brings us to a new horizon of upgrading the methods and techniques of teaching foreign languages. Contrastive teaching Russian as a foreign language is based on the similarities and the differences between languages.

The research demonstrated that while the English language has no indicators of agreement between a noun and an adjective or a pronoun, Russian and Swahili have such 
indicators, the former has inflexions, the latter has prefixes. In our opinion, these morphological specifics are useful for providing students' conscious transference and preventing their interference.

\section{Referencias}

Adonina, L.V., Adonin, R.F. \& Fisenko, O.S. (2017) Cognitive trend in modern science of language: materials for the organization of academic work in classes of the philological profile. Language and Personality in a Multicultural Space. Digest of articles. Edited by I.N. Avdeeva. Russia, Moscow, 34-143

Adonina, L.V., Lazarev, S.V., Smirnova, S.V. \& Fisenko, O.S. (2017) Training for professional activity in Russian of "Public Relations" speciality foreign students. Ed.: Lazarev S.V. Russia, Moscow, 50

Fisenko O., Nikitina V. \& Bodrova T. (2019) Semantic-cognitive approach to the study of a language person in the system of human and individual values. Chile, Santiago, 106112

Fisenko, O.S. (2015) The mental-linguistic space of the Russian religious and philosophical discourse of the late XIX - early XX centuries. Actual problems of science, education and social work. Collection of scientific articles. RGSU branch in Lyubertsy; Institute of Psychology, Sociology and Social Relations GAOU VO MGPU. Russia, Moscow, 194-200

Gromova, N.V., Okhotina, N.V. (1995) Theoretical grammar of Swahili [Gromova, N.V., Okhotina, N.V. (1995) Teoreticheskaya grammatika yazyka suakhili.] Moscow, Russia, 319

Korotaeva, A.V., Demintsevoy, E.B. (2008) Interracial and interethnic relations in modern Tanzania: collection of academic papers of Russian Comprehensive Expedition to the United Republic of Tanzania: 2005 [Korotaeva, A.V., Demintsevoy, E.B. (2008) Mezhrasovye i mezhetnicheskie otnosheniya v sovremennoy Tanzanii: Trudy Rossiyskoy kompleksnoy ekspeditsii v Ob"edinennoy Respublike Tanzaniya Sezon $2005 \mathrm{~g}], 253$

Leontyev, A.A. (1970) Some problems of teaching Russian as a foreign language (psychological works) [Leontyev, A.A. (1970) Nekotorye problemy obucheniya russkomu yazyku kak inostrannomu (Psikholingvisticheskie ocherki)]. Moscow, Russia, 87

Lions, D. (1978) Introduction into theoretical linguistics. [Layonz, D. (1978) Vvedenie v teoreticheskuyu lingvistiku]. Moscow, Rossiya, 543

Malova, A.V., Tifanova, M.F. The dialogue of cultures. The communicative development of students' cultural and linguistic competence. The English language. [Dialog kul'tur (2006) Razvitie kommunikativnoe i lingvostranovedcheskoy kompetentsii uchashchikhsya. Angliyskiy yazyk. A.V. Malova, M.F. Tifanova i dr]. Volgograd, Russia, 80

Rubinstein, S.L. (2000) The basics of psychology [Rubinshteyn, S.L. (2000) Osnovy obshchey psikhologii]. Moscow, Russia, 685

Safonova, V.V. (2006) The methodology of teaching Russian as a foreign language: a basic lecture course [Safonova, V.V. (2006) Metodika obucheniya inostrannym yazykam: bazovyy kurs lektsiy]. Moscow, Russia, 239

Vagner, V.N. (2002) Language-focused methodology of teaching Russian as a foreign language. Traditions and innovations in the professional activity of teaching Russian as a foreign language: a monography. Eds.: S.A. Khavronina, T.N. Balykhina [Vagner, V.N. (2002) Lingvoorientirovannaya metodika prepodavaniya russkogo yazyka kak inostrannogo. Traditsii i novatsii $\mathrm{v}$ professionalnoy deyatelnosti prepodavatelya russkogo yazyka kak inostrannogo: Uchebnaya monografiya / Pod obshchey red. S.A. Khavroninoy, T.N. Balykhinoy]. Moscow, Russia, 428 


\section{Financiamiento:}

* This paper has been support by the RUDN University Strategic Academic Leadership Program. 